\title{
JUURNAL.RU
}

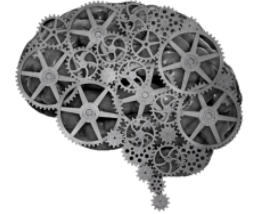

COMPANY GROUP "INTELLEKT"

\author{
Силантьева М., Илямакова Е. \\ Ульяновский государственный педагогический университет имени И. Н. Ульянова \\ Ульяновск, Россия
}

doi: 10.18411/1j2016-5-4-10

\section{Формирование коммуникативных УУД у младших школьников посредством дидактической игры и музыкотерапии}

Тема формирования коммуникативных УУД в начальной школе имеет большую актуальность в современной системе образования России, где наблюдаются изменения, представляющие собой этап расцвета новой школы, направленный следующий виток в образовании. Вследствие этого создаются и развиваются новые подходы в педагогической практики и теории учебновоспитательного процесса. К этим подходам без сомнения относятся и музыкотерапия и дидактическая игра.

Дидактические игры - это разновидность игр с правилами, специально создаваемых педагогической школой в целях обучения и воспитания детей, формирования коммуникативных УУД. Дидактическая игра - это игра только для учащегося, а для взрослого - это способ обучения. Цель дидактических игр облегчить переход к учебным задачам, сделать его постепенным.

Дидактическая игра представляет собой сложное, многогранное явление. Для организации и проведения дидактической игры необходимы следующие условия: наличие у педагога определенных знаний и умений относительно дидактических игр; выразительность проведения игры; необходимость включения педагога в игру; оптимальное сочетание занимательности и обучения; средство и способы, повышающие эмоциональное отношение детей к игре, следует рассматривать как не самоцель, а как путь, ведущий к выполнению 
дидактических задач; используемая в дидактической игре наглядность должна быть простой, доступной и емкой.

Дидактическая игра - вид непродуктивной деятельности, мотив которой заключается не в ее результатах, а в самом процессе, в который мы включаем формирование коммуникативных УУД. При использовании дидактической игры на уроках необходимо учитывать индивидуально - типологические особенности учащихся, уровень их успеваемости, обучаемости. Эффективна в данном случае и парная работа учащихся, так учитель может организовать работу слабого ученика в паре с сильным, который помогает первому выполнить игровые действия.

Дидактической игра в начальных классах должна быть изложена кратко, лаконично, доступно. В некоторых играх учитель с целью увлечения детей игровым замыслом создаёт ситуацию ожидания, загадочности. Успех игры зависит от особенностей организации учителем самой игры. Игра, содержащая несколько правил, расчленяется на составные части и выполняется поэтапно. В большинстве игр целесообразно вносить элементы соревнования, что повышает активность детей в процессе обучения. Форма проведения игры может быть разной: коллективной, страховой и индивидуальной. При объяснении нового материала или при его первичном закреплении целесообразно проводить игру со всем классом.

Музыкотерапия - это психотерапевтическо - педагогический метод, основанный на оздоровительном воздействии музыки на физиологическое и психологическое состояние человека. Многочисленные методики музыкотерапии предусматривают как целостное и изолированное использование музыки в качестве основного и ведущего фактора воздействия (прослушивание музыкальных произведений, групповое музицирование), так и дополнением музыкальным сопровождением других коррекционных приемов для усиления их воздействия и повышения эффективности.

«Детям с особыми нуждами, прослушивание музыки и игра на 
музыкальных инструментах может дать стимул к речевому общению... Занятия музыкой развивают у ребенка умение слушать, соблюдать очередность и произносить звуки. Все это очень важно для последующего развития речи» [3, с. 86].

Навыки поведения и выполнения учебных задач в музыкальном зале формируются не сразу у только что пришедшего ребенка. У ребенка отсутствуют социальные навыки общения, в результате которых они пугаются войти в круг, испытывают страх, тревогу или неловкость от присутствия другого человека. Поэтому введение ребенка на музыкальные занятия происходит очень постепенно, поэтапно.

С помощью музыки и танца педагоги решают множество коррекционновоспитательных задач, основные из которых - это формирование коммуникативных УУД. Именно на музыкальном занятии в круге решаются задачи заражения положительными эмоциями и формирования чувства коллективизма от совместной деятельности. После занятия в музыкальном зале ребенок становится более раскрепощенным, открытым, доверчивым, контактным, послушным, управляемым, подчиняемым. У некоторых детей именно в музыкальном зале появляется первая улыбка, сменяющая сверхсерьезное выражение лица.

Таким образом, мы можем сделать вывод, формирование коммуникативных УУД посредством дидактической игры и музыкотерапии будет успешным в современных условиях системы образования. 


\section{Литература:}

1. Букатов В. М., Ершова А. П. Нескучные уроки: обстоятельное изложение социо/игровых технологий обучения школьников.—-СПб., 2013.

2. Букатов В. М. Педагогические таинства дидактических игр.- М., 2003.

3. Ньюмен С. Игры и занятия с особым ребенком. Руководство для родителей, - М.:Теревинф, 2016 - 236 с.

4. Старчеус М. С. Музыкотерапия // Психологический лексикон / под общ. ред. А. В. Петровского. - М. : ПЕР СЭ, 2007. - 416 с. 